\title{
RILA, Porto Murtinho and its cultural heritage: perspectives for preservation
}

\author{
RILA, Porto Murtinho e seu patrimônio cultural: perspectivas para a preservação
}

\section{RILA, Porto Murtinho y su patrimonio cultural: perspectivas de conservación}

\author{
Rodrigo Mendes de Souza ${ }^{1}$ \\ Juliana Villela Junqueira² \\ Maria Margareth Ribas Escobar Lima ${ }^{3}$ \\ Éricka Santos Silva ${ }^{4}$ \\ Mariana de Barros Casagranda Akamine ${ }^{4}$
}

Received on 01 Jul. 2021; revised and approved on 17 Sept. 2021; accepted on 13 Oct. 2021

DOI: http://dx.doi.org/10.20435/inter.v22i4.3434

\begin{abstract}
As part of the studies developed by the University Network of the Latin American Integration Route (UniRila), this proposal intends to contextualize the municipality of Porto Murtinho in the process of occupation of the interior of the South American continent, understanding the Latin American Integration Route (RILA) as the culminating event of the process of territorialization-deterritorialization-reterritorialization of the region. For this purpose, historical, economic, geographic and geological aspects are considered, without which the conditions of urbanization would not be fully understood and public policies would be deficient. Thus, it is intended to draw attention to the impact that the production and export of commodities has on the territory in question.
\end{abstract}

Keywords: Bioceanic Route; infrasctructure; agribusiness; water; preservation.

Resumo: Como parte dos estudos desenvolvidos pela Rede Universitária da Rota de Integração Latino Americana (UniRila), esta proposta pretende contextualizar o município de Porto Murtinho no processo de ocupação do interior do continente sul-americano, entendendo a Rota de Integração Latino Americana (RILA) como evento culminante do processo de territorialização-desterritorialização-reterritorialização da região. Para tanto são considerados aspectos históricos, econômicos, geográficos e geológicos, sem os quais as condições de urbanização não seriam compreendidas plenamente e as políticas públicas se mostrariam deficitárias. Pretende-se chamar a atenção para o impacto que a produção e exportação de commodities têm sobre o território ora em questão.

Palavras-chave: Rota Bioceânica; infraestrutura; agronegócio; água; preservação.

Resumen: Como parte de los estudios desarrollados por la Red Universitaria de la Ruta de la Integración Latinoamericana (UniRila), esta propuesta pretende contextualizar al municipio de Porto Murtinho en el proceso de ocupación del interior del continente sudamericano, entendiendo la Ruta de la Integración Latinoamericana (RILA) como evento culminante del proceso de territorialización-desterritorializaciónreterritorialización de la región. Para ello se consideran aspectos históricos, económicos, geográficos y geológicos, sin los cuales las condiciones de urbanización no se entenderían cabalmente y las políticas públicas serían deficientes. Así, se pretende llamar la atención sobre el impacto que tiene la producción y exportación de commodities en el territorio en cuestión.

Palabras clave: Ruta Bioceánica; infraestructura; agroindustria; agua; preservación.

\section{INTRODUCTION}

The Bioceanic Corridor will be a lever for the development of the Porto Murtinho city and its surroundings, enhanced by the strategic location of the municipality, favoring its logistical vocation and, in parallel, tourism. After the construction of a binational bridge and studies for

\footnotetext{
${ }^{1}$ Universidade Federal de Mato Grosso do Sul, Campo Grande, Mato Grosso do Sul, Brasil.

2 Universidade de São Paulo, São Paulo, São Paulo, Brasil.

${ }^{3}$ Instituto do Patrimônio Histórico e Artístico Nacional, Campo Grande, Mato Grosso do Sul, Brasil.

${ }^{4}$ Universidade Católica Dom Bosco, Campo Grande, Mato Grosso do Sul, Brasil.
} 
a railroad, the state of Mato Grosso do Sul will be connected by dry route to Carmelo Peralta, in Paraguay. Completion is scheduled for mid-2022. This bridge allows for greater proximity to the Pacific ports in Chile (ASATO; GONÇALVES; WILKES, 2019, p. 142). There is a large estimate, for example, of massive investments, in part already materialized in the construction of three ports on the Paraguay River, with the possibility of becoming an import and exportation center.

With approximately 3,503 km in length, Latin American Integration Route (RILA) is one of the few projects developed within the scope of South American Infrastructure and Planning Council and Integration of the South American Regional Infrastructure (COSIPLAN/IIRSA) that is still in progress. It is the result of the perennial political convergence of South American countries around projects aimed at the flow of production, most notably from the border area located in the interior of the continent. Aiming to fill the infrastructure gap necessary to connect the Brazilian Atlantic coast to the northern Pacific coast of Chile, from the Brazilian point of view, it aims to integrate the existing infrastructure and to be implemented between Mato Grosso do Sul and São Paulo that to be developed in Paraguayan, Argentinean and Chilean territories. Considering only the road perspective, there remain the paving of approximately $240 \mathrm{~km}$ in the Paraguayan stretch and $20 \mathrm{~km}$ in Argentina.

From IIRSA's point of view, RILA integrates a series of projects whose objective is to provide logistical, energy and communication infrastructure, clearly expressing the foundations of contemporary society as defined by Milton Santos (2008) as a technical-scientific informational means. These initiatives are distributed across the continent and organized by Integration and Development Hubs (EID), aiming to realize latent potentials in each area. Thus, it is worth remembering that, if RILA is contained in the Central Interoceanic axis (IOC), the same region is encompassed by other axes, namely EID Paraguay-Paraná Waterway and EID Capricórnio, with the latter surrounding the Porto Murtinho region to the south, East and West.

The EID IOC is contained between the $15^{\circ} \mathrm{S}$ and $25^{\circ} \mathrm{S}$ parallels and between the $460 \mathrm{O}$ and 7100 meridians, a region whose rainfall indices exceed $1000 \mathrm{~mm} /$ year, with the exception of the Chaco. On the Brazilian side, the region is really attractive for three specific crops: soybean, pine and eucalyptus, given their respective demands for water.

Initially thought of as a road link, the Bioceanic Route crosses a region of confluence of flows from the Platinum and Amazon Basin and from the Atlantic and Pacific paths to the interior of the continent, over an extensive portion of the Guarani aquifer, Mato Grosso do Sul, being the unit policy with the largest portion of its area.

The geographical condition of Mato Grosso do Sul should not be understood only from its relationship with Paraguay, but with the entire La Plata Basin, with the Chilean and Bolivian markets. Considering RILA, Porto Murtinho is $1400 \mathrm{~km}$ from Santos, Brazil and $2000 \mathrm{~km}$ from Antofagasta in Chile. However, in a straight line it is almost equidistant both from the aforementioned ports - both at the same latitude, respectively 23056' and 23039', forming an isoceles triangle - as well as from the ports of Paranaguá and Itaguaí in Brazil and, in Chile, of Mejillones, close to Antofagasta, Iquique, where there is a free zone, being a little farther from Arica, the last Chilean port to the north, on the border with Bolivia. Located at 21041'56"S e 57052'57'on the banks of the Paraguay River, Porto Murtinho is in a privileged location. A condition that favors not only the distribution of current local production for export (cellulose, soy, meat and iron), but it will also allow the incorporation of higher value-added goods in this list.

The territory cut, organized and articulated by the bioceanic corridor will go through this process, without, in fact, a connection other than the road making it possible to cross the 
barriers between the Pacific and the Atlantic, leaving the Andes as an obstacle to be overcome by road, to constitute a severe bottleneck for an attempt dammed up for centuries. In fact, the type of truck that transports these loads in Brazil cannot run on the winding route on the Chilean stretch of RILA, implying transshipment infrastructure for the same modal. As a result, some studies indicate that RILA's economic viability is greater for products with high added value and that can be transported by container, creating potential conditions to diversify Mato Grosso do Sul's exports and also enhancing the state as a distribution hub in the interior of the continent of products coming via the Pacific, Atlantic and the Brazilian Southeast.

Emphasizing this road character in RILA's understanding, a refinery and an oil transformer will be built in Mato Grosso do Sul, in Campo Grande and Terenos, respectively, with the possibility of installing a diesel refinery in the future. Although they aim to serve the domestic market, being private investments, their strategic position with the implementation of RILA will allow not only meeting this initial demand, but also the future and also the distribution of its production throughout the Southern Cone, which will be supplied by raw material coming from Argentina and Bolivia.

If articulated with the waterway and rail modals, RILA will be able to efficiently connect the productive sectors and consumer markets of the Southeast and Midwest of Brazil, with the respective demands of Chinese and other Pacific countries, as well as the mineral resources of northern Chile and from the central-east of Bolivia. This will leverage new national and transnational productive arrangements - which may include from the processing of Brazilian soybeans in Argentina, allocation of regulatory stocks in Chile, distribution of petrochemicals and fertilizers to the Southern Cone etc. -, implying a new territorial organization, which is inserted in the constant process started in the beginning of the 16th century of territorializationdeterritorialization-reterritorialization, spread throughout geography by the acronym tdr, and originated in the thought of F. Guattari and G. Deleuze. RILA is part of the streak of occupation and integration projects in the interior of the South American continent, reorganizing this territory, ranging from Jesuit reductions, through cartography that sought to locate and give shape to the mythical Lagoa de Xarayes (Laguna de los Xarayes ), to the projects of the Interstate Commission of the Paraná and Uruguay Basins (CIBPU) for the inland navigation of the continent under the responsibility of engineer Paulo Mendes da Rocha, arriving in Itaipu and not stopping there.

\section{MS COMMERCIAL PROFILE}

When considering the main trading partners of Mato Grosso do Sul, China, Bolivia (because of the Brazil-Bolivia gas pipeline, the energy input pays customs tariffs in the state), United States, Chile, Hong Kong, Netherlands, Argentina and Paraguay, in this in order of importance, the significance of RILA and the need not to restrict it to the road modal is evident in order to boost the state's economy. In its current form, it will shorten the route to the main Asian markets by six days, will allow more immediate access to the American West coast and may be a means of transporting production from the Brazilian Southeast that arrive by sea to other South American countries. However, if approached from a multimodal perspective, its limits would be different.

The Andes Mountain range imposes severe limitations on realizing the potential of a bioceanic route, with altitudes that easily exceed 4,000 meters. To carry out its transposition by a winding road is to reduce the Herculean effort of crossing the continent to the same way as the 
troops of mules and slaves that the colonizers employed. A form correlated with South American aspirations in the 21st century is needed. Although there are studies about a railroad crossing the Andes from Salta, Argentina, and even studies for a tunnel under the mountains, the more concrete prospect that the road is indicative of the quality of the process that is starting. This insufficient achievement, correlated to the form that the desire for transposition takes in reality, will have implications for the structuring of the region, determining the coming reterritorialization. It is evident that the technical, scientific and informational means incident on this territory will have a rearrangement and the question that remains is what is the desirable reason or meaning for this process, since it will lead to new uses of the territory and, specifically, of the soil, in Porto Murtinho. So that several layers were deposited on it, the global, the continental, the national, the state and the local, expanding and dynamizing the relations and flows of the region internally and on a global scale.

Despite the role of waterways and railroads in realizing the potential of RILA, greater river port infrastructure on the Brazilian side is urgent, as of the 29 large ports contained in the EID IOC, most are maritime and among the few rivers they can those from Concepción, Asunción, Santa Fé Corrientes should be mentioned. As for the railways, the different gauges of the trains, the absence of connections that meet the scale of local production and the flow of goods, services and people who will pass through the region constitute a limit to be overcome. Although navigation in the Upper Paraguay is very limited, either because of the winding route or the dry period, where only shallow draft vessels can travel, the municipality of Porto Murtinho is in a privileged condition, as from Fecho dos Morros, the upstream from its urban core and the bridge to be built, the river takes on a less winding layout, widens and acquires greater depth.

Of this, on the Brazilian side, the state of Mato Grosso do Sul is, par excellence, the territory of the RILA route, whose intersection with the Paraguay river determines the municipality of Porto Murtinho as its nodal point, and its double on the other bank, the municipality Paraguayan Carmelo Peralta, both historically linked to a waterway with potential yet to be fully realized. It is a remarkable territory in several layers - geographical, ethnic, historical, productive and imaginary - and with notorious isolation from the point of view of European colonization until the second half of the 19th century, when the Paraguay river was opened to regular navigation until the vicinity of Cuiabá. Until now, the communication between Mato Grosso and the region with the capital Rio de Janeiro and the Atlantic coast had been via Goiás. This situation was reinforced by the discovery of gold further north, in the Guaporé basin, resulting in the establishment of routes between Mato Grosso and Pará, by the Madeira, Mamoré and Guaporé rivers and from there to the Atlantic.

Given the initial isolation, a supply economy with a certain diversification was formed in the outskirts of Cuiabá, protected from other production centers by distance, which, however, limited it to the less dynamic regional consumer market. Efforts for another path to Rio de Janeiro than the one through Goiás continue into the 19th century on two fronts. One in the Paraguay river basin and the other further east, overland, on what became the Pequiri path and from there to the Paranaíba River. In the first, we can place the establishment of military colonies in Nioaque (1855), Dourados (1856), Miranda (1870), the Paraguayan War (1870) and the "pacification" of the Bororo and other ethnic groups. In this process, the Mato Grosso do Sul region has become the largest theater of war on Brazilian soil since then. The second is the result of successive attempts from 1808 to 1832, among which Luíz D'Alencourt in 1818 stands out. The occupation 
of the south of the state only intensified in the Pantanal and in the vicinity of Serra de Maracaju after the Paraguayan War, with this mountain range making the transition between the lowland and wetlands of the Pantanal to the Brazilian plateau in the south of the state, the gateway to the Langsdorff expeditions, by Guido Boggiani and Claude Lévi-Strauss, which narrates their ascent to the Brazilian plateau from the Pantanal to the north and described in "The widest horizons".

This territorialization on two fronts ends up establishing livestock as the main economic activity in the region, a process accentuated in 1837 with the tax exemption that benefited the installation of the Rafael Del Sar Descalvado charqueada to the south of Cáceres on the banks of the Paraguay River, reaching 5 thousand prayers slaughtered annually. In the wake of this process, trader Thomaz Larangeira, who was already exploring yerba mate in Paraguay, obtained a concession to explore the product in the Porto Murtinho region (1880). Cia Mate Larangeira expanded its concessions from 1890 onwards, building a port destined for export, here the exporting vocation of Mato Grosso do Sul emerges in the municipality's territory once again, its production reaching $10 \%$ of Brazilian exports of the product.

During the Corumbá period, it assumed prominence in the control of the territory, due to its fluvial-maritime connection with the capital, which was more direct than the existing terrestrial ones - which used to take up to 5 months. Although Corumbá does not show a vertiginous growth, it is from there that the mechanism for controlling the territory from Rio de Janeiro is manifested, with the arrangement of new technical and informational means in that territory, for example, steamboats and mail. The process that starts in Porto Murtinho now aims to overcome the logistical difficulties that prevent an increase in the scale of local production with a view to global markets.

In this territorialization process, the mining regions of Brazil discovered in the 17th and 18th centuries are inserted in the world economy through slave labor relations and consumption of means of production and consumer goods. In the occupation of the territory that began in Cuiabá in the 18th century and continued to Corumbá in the 19th century, two production-distributionmarketing circuits were consolidated, the first linked to foreign markets, with the export of ores (gold) and even rubber for a short period. and then leather, skins, jerky, yerba mate and import of luxury items (wines, silverware, porcelain, etc.) and a second aimed at meeting the needs of the working mass, initially slaves. It is necessary, in view of this t-d-r process, that both the Master Plan of Porto Murtinho and other interventions aimed at preparing the municipality for RILA break these two separate circulation circuits with a project that generates development and not just growth.

Difficulties of access and isolation, combined with the establishment of livestock as the main economic activity throughout the 19th century, created demographic gaps in Mato Grosso from the point of view of the central government (Empire and Republic), so that, despite the population leap from 60,000 inhabitants in 1872 to 2.51 million in 1980, a dense network of cities was not developed, reaching in the 1980s a demographic density close to that of the Amazon (2.04 inhabitants/km2).

Considered the former state of Mato Grosso, there was a pendular movement from an extractive economy focused on the foreign market - mining in the 18th century - to one focused on the internal market (livestock, 19th and early 20th centuries), which was reformulated and jointly with soy and cellulose, they are once again turning to the foreign market. This movement also corresponds to the successive processes of territorialization-deterritorialization reterritorialization 
that shaped its territory, with a shift of its economic center from the north (Cuiabá) to the south (Corumbá) from the 19th century onwards and from the 20th century onwards to Campo Grande, and at the end of the 20th century again to the North, due to the expansion of the agricultural frontier into the Amazon forest. It also corresponds to each of these inflections the introduction of certain technical objects in its territory, namely, respectively, the steamboat with the opening of the Paraguay River to navigation and other infrastructures related to the cultivation of yerba mate to privilege Corumbá, the implementation of northwestern Brazil railway in 1920, which makes Campo Grande a point of convergence and irradiation, and finally the chemical and genetic agricultural techniques that create the conditions for the northern expansion of soybeans.

Thus, the disposition of new technical objects - railroad, steam navigation, post office, etc. - on the territory of Mato Grosso integrates it with the supply of the national and international market. A new international productive rearrangement between the 1920s and 1970s, with English rubber plantations in Southeast Asia and the replacement of Brazilian mate herb in Argentine imports, marked the region's decline as agriculture became consolidated as the main activity.

Currently, the production on Porto Murtinho region has three main means of transportation, via waterway along the Paraguay River, via highways to the Brazilian seaports, most notably Santos and Paranaguá, or to the Argentinean ports. From these points, it goes to China via the Strait of Magellan, Cape of Good Hope or the Panama Canal.

Considering the concept of Agricultural Productive Region used by geographer Denise Elias, with the implementation of RILA, the rearrangement of the region corresponding to soy, cellulose and animal protein will be accentuated, where urbanization will focus on meeting the needs attached to the respective production chains. Mato Grosso do Sul has a productive profile linked to exports, mainly to Asian markets, so that RILA will mean gains in competitiveness and a better insertion of the state in global production chains. Thus, it was expected a greater concentration of people, financial resources and technical, informational systems in the cities articulated by RILA, with the correlated changes in the production of urban space.

According to Elias (2011):

The RPAs are the new agricultural productive territorial arrangements, the territories of the agro-industrial networks, chosen to receive the most expressive productive investments inherent to globalized agribusiness, representing its most competitive areas. In them are found parts of the spatial circuits of production and cooperation circles of important agricultural commodities, evidencing the territorial dynamics of agribusiness. (ELIAS, 2011, p. 77).

In these regions, agro-industrial corporations are, as a rule, the largest private agents in the production of the territory in the urban and agrarian space. They are characterized by the intensification of country-city relations, determining a specific urbanization pattern, in which the agro-industrial production cannot do without certain processes that take place in the urban space adjacent to the agricultural production areas. This results in cities with functional arrangements aimed at agrobusiness, in which the production of urban land, its use and occupation are conditioned according to its logic, to the detriment of broader visions, to contemplate interests not represented in the dynamics of agribusiness. Historically, in the former Mato Grosso, we see a similar relationship with the two production-distribution-marketing circuits, in both cases - current and historical - a specialization of the territory that also generates a dichotomy. Geographically, the two cases find correspondence in the horizontalities and verticalities proposed by Milton Santos (2008) in "The nature of space": 
[...] there are extensions formed by points that add seamlessly, as in the traditional definition of region. These are the horizontalities. On the other hand, there are points in space that, separated from each other, ensure the global and economic functioning. These are the verticalities. Space is made up of one and the other of these cuts, inseparably. (SANTOS, 2008, p. 284).

Completing this definition, the author relates the former to concrete production, circumscribed in a cooperation limited by place. The verticalities could correspond to other aspects of production such as circulation, distribution and consumption. It is the interactions between these two categories that determine Porto Murtinho as a point of interest in this study and in the outline of RILA.

In this sense, this territory will be characterized by the accentuation of direct relations with the centers of power and global consumption, in a rearrangement of local and regional scales in function of the international one, giving another configuration to the territory. Thus, the aforementioned dichotomy takes place with agricultural production with state-of-the-art, modern and rationalized technology, which, for this very reason, implies a refunctionalization of the cities adjacent to this production, forming the nodes of global agribusiness chains; on the other hand, this interaction between horizontalities and verticalities does not exclude traditional forms of production and other divisions of labor not integrated into global chains, elements that are generally related to the cultural landscape.

This d-t-r implies some common processes in cities linked to agribusiness: implementation of high technology in agriculture; concentration of capital and technology; marked changes in land use and occupation; replacement of food production by the production of commodities in monocultures, in a clear process of replacing local knowledge by the verticality of contemporary techniques.

It can be understood as a point, but also as a technical scale, Porto Murtinho will be the object of several interventions in this sense, entering a phase of technical synchronization, articulated with other devices elsewhere, forming a system that operates in a connected way. What is placed for the municipality is its insertion in a subsystem of hegemonic techniques characterized by the dispersion of production stages and the centralization of command, where each of these elements has a functional interdependence described by Milton Santos with the words of J. Baudrillard in "The System of Objects: [...] each important piece is so dependent on the others by reciprocal exchanges of energy that it can only be what it is" (BAUDRILLARD, 1995, p. 11).

Here, the word of energy opens an important path for understanding the horizon that stretches out in front of Porto Murtinho. If for Luis Férnandez-Galiano (1991, p. 24) architecture can be considered "[...] an energetic organization that stabilizes and maintains material forms", historically, the city and the territory are materializations of this process. Inflection point in this relationship are the transmission networks, responsible for the dissociation between the place of production and the place of consumption. It is about the appropriation of a territory, or even its deterritorialization-reterritorialization, whose formalization takes place in dams, aqua-oilgas-pipelines and roads and other infrastructures. Technical objects redefining and planning the landscape, creating the invisible presence that Michael Jakob (2001, p. 9) speaks about. He also says: "[...] we live in energy landscapes, territories whose forms and elements are/are determined energetically". Spatial separation makes it possible to relegate the negative effects of energy production to a distant place. 
This reasoning about energy is here extrapolated to water. To encompass the scale of the overlap between these two elements, we don't need to resort to Einstein's formula to equate matter and energy, just think of the California State Water Project (SWP), a set of dams, hydroelectric plants, aqueducts and canals that serves 23 million people, being one of the largest potable water and energy supply infrastructures in the world. It produces $6500 \mathrm{GWh}$ per year and, however, after pumping water at heights of 878m over the Tehachapi mountains and transporting it over a distance of $489 \mathrm{~km}$ - the main stretch of the California Aqueduct - through a network of more than $700 \mathrm{~km}$ in length, it ends for consuming $5100 \mathrm{GWh}$, being the largest energy consumer in the state.

Thus, says Denise Elias:

With the fluidity possible thanks to the construction of the engineering systems of transport and communications that are now installed in the areas of diffusion of agribusiness, exchanges of various natures are intensified, many of them previously non-existent, with major impacts on social and in the territory, reformulating the old urban system. The expansion of agroindustrial networks not only had repercussions on the technical structure of their respective economic activities, but also had profound effects on labor relations, transforming the set of norms and standards that regulate them. As a result, there is a new social and territorial division of labor, with consequences on the demographic and employment structure, which also help to better understand the accelerated urbanization process, which takes place on new bases, and generates new socio-spatial practices. (SANTOS, 2008 apud ELIAS, 2011).

After cellulose, soybean is Mato Grosso do Sul's main export product. The commodity is extremely dependent on water, making up $90 \%$ of the plant's weight and the grain absorbing half its weight in water to germination. From this we take the importance of hydrological conditions for this crop, which are determined by geology and climate. The first concerns the availability and distribution of underground water storage structures; the second refers to the abundance of precipitation, its distribution in time and space and its role in the recharge of the aforementioned structures. In Mato Grosso do Sul, the combination of these factors create extremely favorable hydrological conditions for the cultivation of soy, as the state has almost all of its territory located on the Guarani Aquifer and has annual rainfall exceeding $1000 \mathrm{~mm}$, losing only in productivity per hectare for the Paraná, with $3108 \mathrm{~kg} / \mathrm{ha}$ and $3288 \mathrm{~kg} / \mathrm{ha}$ respectively.

Located in the intermediate geographic region of Corumbá and the immediate geographic region of Jardim, in the flooded areas of the Alto Paraguai basin, the municipality of Porto Murtinho, although in a privileged situation, limited by the Paraguay rivers to the west, Nabileque to the north and Apa to the south, configures itself historically as a place of passage. Whether due to the transitory geography dictated by floods and ebbs, or the fierce defense of their territory by native peoples or the absence of resources of interest to the first European colonizers, urban/ occupation nuclei were not established beyond the Jesuit missions in the 16th century, which constituted the Province of Itatins. Condition evidenced by the contrast with the development of Buenos Aires and Asuncion, founded on the same process of occupation and recognition of the territory by the Spaniards. Area originally belonging to the Spanish crown, but with little effective occupation and in practice occupied by the Portuguese over the centuries.

The section of the Upper Paraguay stretches from the mouth of the Jauru River to the mouth of the Apa River, where the urban center of Porto Murtinho is located, a passage route from the region upstream of the Paraguay River to the Tietê-Paraná waterway, to Argentina and the basin from Prata, passing through Asunción, Concepción and others. It is located near Fecho 
dos Morros, located to the north, a geographic accident that divides this stretch of the river into two parts according to the following changes: its average inclination goes from $2.3 \mathrm{~cm} / \mathrm{km}$ to 1.3 $\mathrm{cm} / \mathrm{km}$; its margins widen and become more defined, going from $100 \mathrm{~m}$ in the upper stretch to $300 \mathrm{~m}$; its average depth exceeds $4 \mathrm{~m}$ and reaches $10 \mathrm{~m}$.

In this stretch, where the draft is $3 \mathrm{~m}$ during 9 months of the year, $4 \times 4$ convoys of jumbo barges sail, measuring $60 \mathrm{~m}$ in length and $12 \mathrm{~m}$ in width, with a load capacity between 20 thousand and 25 thousand tons. Type of vessel, among others, that will serve the cargo terminals to be built in the city, one of them with operation scheduled for the beginning of next year. These will have the infrastructure to operate with various loads such as grains, fertilizers, ores and petrochemicals. This occurs in a context of expansion of the state's productive matrix with the petrochemical industry and the prominence of cellulose in the state's trade balance.

The construction of the road bridge between the urban center and the Paraguayan city of Carmelo Peralta adds to the present conditions of river, rail and road transport crossing the river, such as the Mal. Rondon (Caceres, Mato Grosso [MT]) and BR-263 road bridges (Corumbá, Mato Grosso do Sul[MS]) and Eurico Gaspar Dutra railway. Thus, the city of Porto Murtinho will become a regional intermodal hub for the circulation of goods, as it will be provided with four modes of transport, namely rail and air (both under study), road and river. The jump in tons shipped in Porto Murtinho between 2018 and 2019 from 600 thousand to 1 million gives the scale of the changes that will impact the municipality.

There is a large estimate, for example, of massive investments, due to the construction of three ports on the Paraguay River, with the possibility of becoming an import and export center. In this way, a new dynamic in the production and use of urban land is established for Porto Murtinho. This one, though seated on a natural foundation, namely the earth, cannot be confused with it.

To understand the situation of the city in the context of the Bioceanic Route and the consequences of its historical, cultural and environmental heritage, it is necessary to activate a series of urban and regional planning concepts. The value of urban space comes from its property of articulating the different elements of the city and the territory, an attribute that will experience a strong increase in Porto Murtinho. This is what Villaça (1998) and Santos (2008) called a point, as a result of the employment and concentration of work and resources in a given location, a process that is accentuated in this context. The effects of displacements and transport routes on urban structure should also be considered, given that these will occur at different levels in Porto Murtinho, from the scale of the neighborhood, through the regional, to the insertion of the municipality in an intercontinental route infrastructure linked to global production chains.

For Villaça (1998, p. 25) regarding the soil:

A third land use value assumes, in our view, growing importance with the socialization of the general conditions of production: what we call the capacity to agglomerate, after socially combining means of production and means of reproduction of a social formation. The third use value that Lojkine talks about is therefore fundamental. This use value resides in the property that has its own urban space to make the different elements of the city relate to each other. It's what we call a location or point.

Complements Santos (2008) when it states that:

[...] Events are also ideas and not just facts. An innovation is a special case of an event, characterized by the contribution to a given point, in time and space, of data that renews a way of doing, organizing or understanding reality in it. But events don't happen in isolation.

INTERAÇÕES, Campo Grande, MS, v. 22, n. 4, p. 1227-1242, out./dez. 2021. 
When we consider the joint happening of numerous events, whose order and duration are not the same, we find that they overlap. This set of events is also an event, of which the singular events that form it are elements. It is not just a superposition, but a combination, since the nature of the resultant is different from the sum of the constituent parts. Another would be the order of combination, another the point at which it occurs, and another would be the result. (SANTOS, 2008, p. 96).

Outlining this succession of events that shape the territory of Porto Murtinho is fundamental to the process of preserving its heritage and understanding the changes that will affect the region. Historically, crossing point of the barges that have supplied Cuiabá since its foundation in 1719 - vessels made from a trunk derived from indigenous canoes, which, measuring about $12 \mathrm{~m}$ by $1.5 \mathrm{~m}$ in width, transported 6 tons and about 25 people - Porto Murtinho has its vocation as a point of convergence, distribution and articulation of Brazilian production reaffirmed by the Bioceânica Route. This fact highlights the cultural character of river navigation for the region, adding meaning to this infrastructure project.

Path of the first European territorialisations, river navigation via the Paraguay River, passing through the former province of Itatins, is intermittent and unsafe due to a singular fact in the entire process of European colonization on the continent, the reconquest by native peoples of a territory already conquered by Europeans. Expelled from the Chaco region, Mbayá tribes moved to the region of the current Pantanal Sul-Matogrossense, a region until then occupied by Jesuit missions, probably with Guaraní Indians. The defeat for the Spaniards brought another significant change for this ethnic group, the dominance of the horse. In this place they find the Payaguás or canoemen, a subgroup of the same ethnic group, with whom they form an alliance and, later, dominate the technique of navigation in canoes. This new knowledge restores the condition of military superiority enjoyed by this ethnic group, keeping it in its condition of noble people and in control of its territory for nearly three centuries. So, until the end of the 19th century, there were frequent attacks by indigenous peoples on Brazilian, European or Paraguayan vessels, as well as expeditions leaving Cuiabá to annihilate them.

In current times this isolation, although smaller, can be seen in the following data. Despite its historic vocation in connecting Brazilian lands to Argentina, Paraguay, Chile and Bolivia, most trade with these countries is via the Atlantic.

\section{MASTER PLAN}

The municipality's border situation raises several questions. The first of them is the alterity - of systems, politics, currency, cultures, languages, experiences etc. - in order to establish a double territorial logic, where on the one hand there is a search for official control and on the other a network trade, cultural, services and even political exchanges through informal border dynamics. In it, the here and there side mix, the line is blurred and a single reality emerges in the contrasts of language, politics, infrastructure and laws. We can exemplify the unfolding of these interactions and major infrastructure works in Brazilian and Paraguayan villages limited by Lake Itaipu, this work being another spearhead of urban involution pointed out by Milton Santos. As an example, it is worth mentioning the policy to encourage Brazilian colonization in eastern Paraguay carried out by the Stroessner government, targeting the marginalized rural population in the process of modernization of the countryside related to the Itaipu hydroelectric project. Concentrations of capital, technology and land ownership were decisive in this process. 
From this it is concluded that t-d-r processes have their engines in state and non-state agents, which manifest themselves, for example, in public policies, community practices, infrastructure and investments, so that territoriality is manifested in overlapping the border.

River or river culture located on the Brazil-Paraguay border, resulting not in a line, but in a border area, with intense interaction between the populations of the two countries, who share, along with the river, ways of life, origin, customs and services, a situation that will be accentuated by the infrastructure projects planned for the region.

Accessible only by river until the mid-19th century, it is an expression of the process of occupation of the territory by Spaniards, Portuguese, Paraguayans and Brazilians and its consequences on indigenous and historical populations. This results in unique cultural, historical and environmental conditions. In order to configure, in the context of heritage preservation, what Alois Riegl (2014) called volatile and non-volatile goods, concepts that can also be extended to immaterial goods and landscapes. From the urban layout, historic buildings, ways of life, production, popular traditions, other social and cultural dynamics that need to have their values thought out in the context that is configured and contemplated in the Master Plan of Porto Murtinho.

Thus, a plan that disciplines and organizes the use and occupation of land in the municipality is urged, which includes the preservation of its historical, cultural and environmental heritage. To do so, it must make use of the various elements of urban policy contained in the City Statute and mentioned above, namely: right of preemption; onerous grant of the right to build; consortium urban operation, expropriation with payments in titles; transfer of the right to build; Urban property and land tax (IPTU) progressive over time; concession of special use for housing purposes.

Among the new land uses that have been installed in Porto Murtinho, we can mention the port terminals under construction, multimodal terminals, cargo processing centers and their respective activities and support services. As a point at which various flows have concurred, compete and will concur, it is up to Porto Murtinho to elaborate these impulses in a codified way, under the risk of becoming a "schizophrenic" city if the definition present in O Anti-Oedipus by G. Deleuze and is considered. F. Guattari.

Although studies do not point to anything close to a vertiginous growth in the municipality of Porto Murtinho, the increases in the port movement in the last two years - without the railroad or even the bridge - indicate an increase in the flow of goods of such magnitude that it will leave indelible marks on the territory of the municipality. This perception should condition the view on the historical and cultural heritage of the municipality, as an example of these processes we cite the villages of Itaipu and the coal towns of the first industrial revolution. In the latter, it is not by chance that the bridges-along with the factory and the train station - were also one of the programs that configure its landscape, although older than the other two, the formal limits of the new construction techniques will be tested. These cities were the last snapshot of the era that preceded the aforementioned dissociation. Thus, linking the parameters for the preservation of Porto Murtinho's Cultural Heritage to the economic cycles that shape and shape its territory is a fundamental strategy in its understanding and systematization.

The road bridge has not yet risen in the landscape, but there are already expressive changes in the cultural landscape of Porto Murtinho. Storage terminals are one of the most prominent interventions in this area, encouraged by PROEXP. These may be articulated with the petrochemical industry that is installed in Campo Grande and Terenos or with a potential soy 
processing industry in the municipality, replacing the realization of this process on Argentine soil via the ports of Timbues and San Lorenzo in Santa Fé, to leverage the gains in competitiveness that RILA provides to Brazilian production.

The potential of RILA already triggers strong speculative pressure on the urban land of Porto Murtinho, and an incipient process of gentrification has already been observed, with part of the population abandoning their own or rented houses, moving to areas outside the dike that surrounds the urban nucleus of the municipality and establishing precarious, flood-prone settlements. Aiming at the permanence of this population and its reconciliation with preservation, the mixed use of buildings should be encouraged, those whose residents are in social vulnerability must be identified and access to technical advice provided, in order to ensure the quality of the housing unit as well as the preservation of heritage.

This process may take several forms, and the land use and occupation ordering will provide guidelines and condition it. The city will face issues such as moderate verticalization reconciled with the limitations to foundations placed by the type of soil in the region and the consequent increase in population density in the area of the current dike or expansion beyond its limits, requiring a whole series of infrastructure works from the opening of roads, energy networks, basic sanitation, macro and micro drainage solutions, or even a new dam, to avoid floods and floods. These possibilities put great pressure on the city's Cultural Heritage, in a process of urban reconfiguration where these assets tend to be demolished, degraded and disfigured through new land uses, new techniques, gentrification processes and real estate speculation resulting from the insertion of Porto Murtinho in a global production chain.

This restructuring will be responsible for demands that until then did not act or were not decisive on the production of the urban space of Porto Murtinho, such as a series of specializations of services linked to global agribusiness production chains, as well as a relative expansion of the tertiary sector to respond to population growth and its potential diversification. The city will be refunctionalized from the point of view of agribusiness from the availability of new technical objects to reorganize its territory. This territorial specialization is directed according to the productive sectors of animal protein, cellulose and soy, but not only. The agricultural space will be characterized by a high technical and normative density, the alteration of these production bases corresponds to the destruction of traditional knowledge and practices and new uses and occupations of the soil, and, sometimes, changes in the agrarian structure. As possible results of this process, the rural exodus and the arrival of specialized urban labor for agribusiness are of great importance for the conformation of the urban center of Porto Murtinho and for the understanding of its impacts from the point of view of the preservation of the cultural heritage. If we consider the commercial insertion of Mato Grosso do Sul nationally and internationally, we see the phenomenon of urban involution described by Milton Santos, which began in the 1980s and was marked by the growth of medium and local cities, a process that coincided with its emancipation from Mato Grosso.

RILA means for Porto Murtinho its insertion as a node of rapid flows in a series of global production chains, mostly linked to agribusiness. In this way, access to land and water becomes fundamental and tends to constitute a point of conflict and exacerbation of inequalities.

The transformations and new demands affecting the original urban core of Porto Murtinho point to a refunctionalization of this centrality, where the function of housing tends to be shifted to new developments that meet the new profiles of residences in other areas or to places where 
the urban land is more accessible to those displaced by real estate pressure. Thus, the guidelines and mechanisms for the preservation of cultural heritage must prevent this area, endowed with public facilities and infrastructure, from losing its living function, reconciling housing and preservation of heritage through a mechanism that allows the readjustment and maintenance of properties while maintaining the mixed-use character current, with housing from different social strata.

In Porto Murtinho case, part of the elite lives in the rural area, but even so, the mixed-use occupation by all social strata of its historic center is evident. In other words, it still presents an arrangement close to that of cities from the colonial period, although it is no longer from this time. In these cities, the center concentrated all urban functions, housing, circulation, commerce, services, productive and administrative activities. The question that remains is: will there be a sectorization movement (squatting plan, dismounting the castle hill) and suburbanization? Under what forces will this or any other movement take place? Although the formulation of the question is more important at this stage than the answer, we know that this original urban nucleus will be constituted during this process in what we call the historic center, in analogy to other cities that have gone through growth processes linked to new cycles productive. These processes tend to change plot patterns, their occupation - housing typologies, the demographic density of the regions and construction techniques. They are also characterized by population decrease, mostly of the higher income population, new uses and types of users, degradation of the built environment and public spaces, elements pointed out by Raquel Rolnik (2006) in "A new place for the old center. In Porto Murtinho, these issues are accentuated given the city's conformation to the perimeter of the dike, which clearly defines this location.

The vocation for housing a large part of the properties identified as being of interest to cultural heritage should be considered. If we consider that the same housing unit serves different historical moments of a society and that its depreciation cycle is relatively long, a policy that integrates the preservation of historic properties with the housing policy to be implemented in the municipality is positive, with a dual purpose: first, to avoid the degradation of the building and, second, to fulfill its social function, as it meets the demand for housing and gives use to deteriorated properties or objects of real estate speculation, preventing a gentrification process in the original nucleus of Porto Cowberry.

The adaptation of civil buildings to new uses allows the maintenance of their use value, however the cost almost always falls on the owner, whose awareness of the cultural importance of the property is essential for its preservation, resulting in the importance of heritage education. In these cases, commerce and service are the types of land use that predominate in listed properties, as the impossibility of realizing all the constructive potential makes housing use less attractive from an investment point of view, however it is worth noting that these are not uncommon. properties are transformed into precarious housing.

The urban center of Porto Murtinho still has enough land stock to assimilate the new demands, without the buildings of interest from the point of view of historical heritage being demolished before the end of their useful life in order to realize the gains attributed to the construction potential of your lot. The possibility of including the retrofit for housing use as a tipping policy is then raised.

Denise Elias, in her studies of agrarian geography, proposes a series of categories for the analysis of Agricultural Productive Regions, whose variations are indicative of the processes 
of reterritorialization of these spaces, namely: use and occupation of agrarian land, here also extended to the urban; industrial branches representing agro-industrial networks; new and specific dynamics of the urban economy; population dynamics and the labor market; infrastructure and urban equipment. When folded over Porto Murtinho, it is possible to identify the fronts where the transformations affecting the municipality took place. With the Bioceanic Route, flows and the consequent fluidity of capitals will increase, redefining points and resizing distances. Wetland water is the soy that feeds livestock in Asia or the cellulose that goes there. Capital flows with water.

Considering what has been exposed here, it is evident that several changes, regardless of their scale, are in place for the production of urban, agrarian and rural space in Porto Murtinho. RILA is part of the history of large occupation and reterritorialization projects in the interior of the continent, in a way that represents not an inflection in this process, but its continuity. Its difference from the previous ones lies in its technical nature and in the world context of the 21st century, where Asia - not only China - emerges as the origin of the main demands that affect this territory. The techniques deposited on its territory will accentuate the verticalities as defined by Milton Santos on a scale that has not been tried until now, disarticulate or rearrange the existing horizontalities and establish new ones. These changes, in turn, will generate impacts on the city's cultural landscape, knowledge, modes of production, urban space and social dynamics. Considering the city's Cultural Heritage, the instruments contained in the City Statute cannot be transposed to the Master Plan as a cold letter, that is, its application cannot be disarticulated from the current context and from the transformations outlined in the horizon. The actual urban nucleus, surrounded by the dike, is an object of preservation interest at the same time that it will be the site of several transformations, which may be accompanied by the categories presented in the previous paragraph.

If the pressure generated by the export of commodities - cellulose, animal protein and soy - has direct consequences on the territory of Porto Murtinho, one of its facets materializes in its demand for infrastructure and water resources, in order to bring water to the center of the debate. By articulating the various layers that define the territory in question - its occupation from the first peoples, its geography, its history, its biome, the social relations present there, its economy, its stock of land for housing, its infrastructure and its global insertion - water must be at the center of the articulation of the elements of the City Statute in the Master Plan of Porto Murtinho. The water presents itself as a paradigmatic thread in the face of the drought of recent years in the interior of the continent, affecting not only Brazil, but also Argentina, Bolivia and Paraguay, with the Pantanal facing its worst drought in 50 years, as well as determining the area inside the dike as privileged for housing. The Mapbiomas (2021) survey, carried out by a group of institutes, universities, companies and researchers points to a loss of $16 \%$ of the water surface in Brazil for the period between 1985 and 2020, while Mato Grosso do Sul leads this index among Brazilian states with $57 \%$ loss. In addition to making navigation in the Upper Paraguay difficult, the lack of rainfall ends up with pastures, facilitates fires and makes irrigation difficult.

For this it is necessary that the public authorities train and provide conditions for the population in the preservation process, providing technical advice and heritage education. It is not about preventing the transformations and changes brought about by RILA, many of them positive and desired, but about shaping this process so as not to deny history or development, and reconcile them. 


\section{REFERENCES}

ASATO, T. A.; GONÇALVES, D. F.; WILKES, E. P. Perspectivas do Corredor Bioceânico para o desenvolvimento local no estado de MS: o caso de Porto Murtinho. Interações, Campo Grande, MS, v. 20, n. especial, p. 141-57, 2019.

BAUDRILLARD, Jean. A sociedade de consumo. Rio de Janeiro, Elfos, 1995, p. 68. 2

MAPBIOMAS. Produtos. Mapbiomas Brasil, [s.l.], 2021. Available at: https://mapbiomas.org/produtos. Access on: 1st June 2021.

ELIAS, D. S. Agronegócio e novas regionalizações no Brasil. Revista Brasileira de Estudos Urbanos e Regionais da UFABC, Santo André, v. 13, n. 2, p. 153-67, 2011

FERNÁNDEZ-GALIANO, L. El fuego y la memoria: sobre arquitectura y energía. Madri: Alianza Editorial, 1991.

JAKOB, Michael. Arquitectura y energía. Revista 2G, Barcelona, n. 18, 2001.

RIEGL, A. O culto moderno dos monumentos: a sua essência e a sua origem. Tradução de Werner Rotchschild Davidsohn e Anat Falbel. São Paulo: Perspectiva, 2014.

ROLNIK, R. Um novo lugar para o velho centro. Vitruvius, São Paulo, 2006. Available at: http://www. vitruvius.com.br/minhacidade/mc164/mc164.asp. Access on: 17 Apr. 2015.

SANTOS, B. S. A Universidade no Século XXI: para uma reforma democrática e emancipatória da Universidade. São Paulo: Cortez, 2005.

SANTOS, M. A natureza do espaço: técnica e tempo, razão e emoção. 4. ed. 2. reimpr. São Paulo: Editora da USP, 2008. V. 1.

SILVA J. S. V.; ABDON, M. M. Delimitação do Pantanal Brasileiro e suas sub-regiões. Revista Pesquisa Agropecuária Brasileira, Brasília, v. 33, n. especial, p. 1703-11, out. 1998.

SOUZA, E. B. C.; GEMELLIE, V. Território, região e fronteira. Revista Brasileira de Estudos Urbanos e Regionais da UFABC, Santo André, v. 13, n. 2, p. 101-16, 2011.

VILLAÇA, F. Espaço intraurbano no Brasil. São Paulo: Studio Nobel, 1998.

\section{About the authors:}

Rodrigo Mendes de Souza: Doctorate student in Theory of Art at the University of São Paulo (USP). Master's degree in History of Art at USP. E-mail: rodrigo.mendes@ufms.br, Orcid: https://orcid.org/0000-0001-7169-9670

Juliana Villela Junqueira: Doctorate student and Masters in Architecture and Urbanism at the University of São Paulo (USP). Graduated in Architecture and Urbanism at the Pontifical Catholic University of Minas Gerais (PUC-Minas). Participates of the research group "Representation of places in Brazilian culture" in the Department of Architecture and Urbanism of the University of São Paulo (FAUUSP). The author's researches focus on the history of architecture, emphasizing the cultural field of modern architecture, as well as on the dialogues of modernism and the social and urban thinking in Brazil. E-mail: jvj.junqueira@gmail.com, Orcid: https://orcid.org/0000-0002-9908-3808 
Maria Margareth Ribas Escobar Lima: PhD at the University of Lisbon, in Portugal. Doctorate in Environment and Development at Anhanguera-Uniderp. Master's Degree in Architecture at the Federal University of Rio Grande do Sul (UFRGS). Graduated in Architecture and Urbanism at the Gama Filho University (UGF). Currently works as a full professor at the Federal University of Mato Grosso do Sul. E-mail: margareth18sr@hotmail.com, Orcid: https://orcid.org/0000-0002-4118-4382

Érika Santos Silva: Doctorate student in Local Development through the Context of Territorialities at the Dom Bosco Catholic University (UCDB). Graduated in Visual Arts at the Federal University of Mato Grosso do Sul and in Architecture and Urbanism at Anhanguera-Uniderp. Participates of the research group "Cultural Heritage, Rights and Diversity" of the Nacional Council of Scientific and Technological Development (CNPq). E-mail: erikasantos.arqdeco@gmail.com, Orcid: https://orcid.org/0000-0003-3715-8015

Mariana de Barros Casagranda Akamine: Masters student in Local Development at the Dom Bosco Catholic University (UCDB). Specialized in Interior Design at UCDB and in Sustainable Environmental Rehabilitation at the University of Brasilia (UnB). Graduated in Architecture and Urbanism at Anhanguera-Uniderp. E-mail: mariana_casagranda@yahoo.com.br, Orcid: http://orcid.org/0000-0001-9605-1061 